\title{
Cyclophosphamide Treatment Expands the Circulating Hematopoietic Stem Cell Pool in Dogs
}

\author{
R. A. Abrams, K. McCormack, C. Bowles, and A. B. Deisseroth, \\ Experimental Hematology Section, Pediatric Oncology Branch, Division \\ of Cancer Therapy, National Cancer Institute, National Institutes of \\ Health, Bethesda, Maryland 20205
}

A B S T R A C T Increased numbers of circulating granulocyte-monocyte precursor cells (CFUc) have been observed in the peripheral blood of man after antineoplastic chemotherapy. We have developed a canine model to study the biologic significance of this phenomenon for hematopoietic reconstitution following hematopoietically lethal exposure to total body irradiation (TBI). After cyclophosphamide administration, a 16-fold expansion of circulating CFUc numbers was observed during the period of rapid leukocyte recovery that occurred after the chemotherapy-induced leukocyte nadir. We had previously noted this association between leukocyte recovery and CFUc expansion in our human studies. After 900 rad TBI hematopoietic reconstitution was attempted with autologous, cryopreserved collections of peripheral blood mononuclear cells obtained either at times of post-cyclophosphamide CFUc expansion (group A, 14 dogs) or without CFUc expansion (group B, 12 dogs). As compared to group B collections, group A collections contained 11-fold more CFUc and were 12.5-fold more potent in fostering hematopoietic recovery after TBI. These results suggest that the expansion of CFUc numbers we observed was accompanied by a similar expansion of more primitive hematopoietic stem cell numbers. We conclude that chemotherapy-induced expansion of circulating CFUc numbers appears to be of substantial import in effecting hematopoietic reconstitution-an observation that may be of significance for further studies of autologous hematopoietic reconstitution in man.

Presented in abstract form at the Advisory Council on Federal Reports, American Society of Clinical Investigation and Association of American Physicians meetings in May 1980.

Dr. Abrams' current address is the Medical College of Wisconsin in Milwaukee.

Received for publication 30 June 1980 and in revised form 16 January 1981.

\section{INTRODUCTION}

Hematopoietic stem cells have been observed to circulate in the blood of several mammalian species including man (1-5). Moreover, studies in animal models have demonstrated that autologous mononuclear cells collected solely from the peripheral blood are capable of effecting hematopoietic reconstitution after an otherwise hematopoietically lethal insult from cytoreductive drugs or irradiation $(6,7)$.

Studies are currently being undertaken in man to define the importance of autologous hematopoietic reconstitution when used in association with intensive antineoplastic therapy (8). In the allogeneic setting, donors of hematopoietic stem cells will by selection tend to be free of major illness. For these healthy donors the need to collect hematopoietic stem cells by means of bulk bone marrow collection is unlikely to be a major problem even though such collection is an operative procedure and requires general or regional anesthesia. Even so, the ability to collect hematopoietic stem cells by a less morbid procedure might be of use in allogeneic settings for donors who are unwilling to submit to an operative procedure. This point was recently demonstrated by Rich et al. (9) in a case report involving immune reconstitution with allogeneic peripheral blood leukocytes in the setting of adenosine deaminase-deficient severe combined immuno-deficiency. In this report the donor (the patient's father) refused to be a bone marrow donor, but consented to leukopheresis.

In the autologous setting the need for bulk bone marrow collection may prove to be a more limiting problem. Most cancer patients who are judged suitable for intensive therapy with autologous hematopoietic reconstitution will have undergone prior surgery and other forms of antineoplastic therapy. It would therefore be desirable to avoid the additional morbidity of another operative procedure. In addition, as we recently reported (10), if large portions of the bony pelvis have been exposed to regional radiotherapy, autolo- 
gous marrow collection may be quite difficult. If hematopoietic reconstitution could be reliably effected using the hematopoietic stem cells collected with one or two leukopheresis procedures, the morbidity and cost of collection of autologous hematopoietic stem cells would be reduced and collection could be done on an out-patient basis. These factors might well broaden the applicability and indications for intensive antineoplastic therapy requiring hematopoietic reconstitution.

Unfortunately, to date, efforts in man at effecting autologous hematopoietic reconstitution using cells collected solely from the peripheral blood have been disappointing $(11,12)$. One important exception to this statement, however, has been in the setting of chronic phase, chronic myelogenous leukemia. In this setting circulating hematopoietic stem cell numbers, as measured by circulating granulocyte-monocyte precursor cells $(\mathrm{CFUc}),{ }^{1}$ are greatly expanded, and autologous collections of peripheral blood leukocytes have been effective in promoting hematopoietic reconstitution (13).

Interestingly, expanded levels of circulating CFUc numbers have been transiently observed in man following the administration of antineoplastic therapy consisting of cyclophosphamide (Cytoxan) and doxorubicin (Adriamycin) either alone (14) or in combination with other agents (15) to patients with malignancies other than chronic myelogenous leukemia. However, whether this chemotherapy-associated expansion of circulating CFUc numbers might have biologic significance for hematopoietic reconstitution has been unclear. Consequently, we have developed a canine model for studying the impact of cyclophosphamideinduced expansion of circulating CFUc numbers on the reconstitutive potency of collections of peripheral blood mononuclear cells. The impetus for the study reported here stemmed directly from our observations in man that chemotherapy-induced expansion of circulating CFUc numbers occurred to a median level of sevenfold in $85 \%$ of patients studied during induction chemotherapy for extensive small cell carcinoma of the lung (15).

\section{METHODS}

This study utilized a canine model specifically designed to study hematopoietic reconstitution. The details of this model with respect to animal selection, care, irradiation, postirradiation supportive care, and criteria for engraftment have been described $(16,17)$. The model utilizes a hematopoietically lethal dose of total body irradiation (TBI) (900 rad midplane dose at $9 \mathrm{rad} / \mathrm{min}$ ) followed by supportive care with parenteral fluids, antibiotics, and platelets. Gastrointestinal and other nonhematopoietic toxicity is mild, and there are no deaths related to gastrointestinal toxicity. Dogs

\footnotetext{
${ }^{1}$ Abbreviations used in this paper: CFUc, circulating granulocyte-monocyte precursor cells; TBI, total body irradiation.
}

failing to achieve hematopoietic reconstitution die from neutropenia and sepsis.

Collection of peripheral blood mononuclear leukocytes was performed utilizing a continuous flow blood cell separator (American Instrument Co., Inc., Silver Spring, Md.) Circulatory access was obtained via a left-sided, jugulocarotid, arteriovenous shunt, maintained for as long as $7 \mathrm{~d}$ with daily heparin flushing. During cell collection, blood flow rate through these shunts to the cell separator was maintained at $40-50 \mathrm{ml} / \mathrm{min}$. The bowl speed of the cell separator was maintained at $1,000 \mathrm{rpm}$. Leukocyte collections containing $3.0-5.0 \mathrm{~g} / 100 \mathrm{ml}$ hemoglobin were obtained at flow rates of $3-4 \mathrm{ml} / \mathrm{min}$ and harvested into $600-\mathrm{ml}$ plastic transfer packs containing 13-15 ml of acid citrate dextrose-National Institutes of Health $(\mathrm{NIH})$ solution A. During collection anticoagulation was maintained with heparin.

After cell collection had been completed, shunts were ligated, allowed to clot, and removed $21 \mathrm{~d}$ later. The resulting neck wound was irrigated with antibiotic solution and allowed to heal for an additional 1-2 wk.

14 dogs (group A) were given intravenous cyclophosphamide $(16 \mathrm{mg} / \mathrm{kg}$ ) on each of $2 \mathrm{~d} 1 \mathrm{wk}$ apart (days 0 and 7) in order to produce expansion of circulating CFUc numbers. This dose and timing were based on clinical observations in patients (15) and preliminary experiments in dogs. Dogs receiving cyclophosphamide underwent shunt insertion on day 10 or 13 after the initial cyclophosphamide dose, and cell collection was performed on days 14-16. Twelve dogs (group B) had collections obtained without cyclophosphamide pretreatment. All dogs studied were healthy male foxhounds of comparable age (8-12 mo) and weight (group A, mean weight $=31.1 \pm 0.7 \mathrm{~kg} ;$ group $\mathrm{B}$, mean weight $=29.1 \pm 0.7 \mathrm{~kg}$, $P>0.10)$.

Parenteral antibiotics were used prophylactically while shunts were in place, during cyclophosphamide-associated myelosuppression, and during wound healing after shunt removal. Ampicillin and gentamicin were given twice daily in doses of $50 \mathrm{mg} / \mathrm{kg}$ and $3.0 \mathrm{mg} / \mathrm{kg}$, respectively.

Samples of blood and bone marrow for CFUc assay were obtained in sterile syringes containing 200-300 U of preservative-free heparin. Aliquots of peripheral blood cell collections were also analyzed for CFUc growth.

Following collection, cells were cryopreserved in $10 \%$ dimethyl sulfoxide as described $(16,17)$, and the frozen preparations were immersed in liquid nitrogen $\left(-196^{\circ} \mathrm{C}\right)$ until needed for reinfusion. Time from cell collection to cell infusion (following TBI) averaged 7 wk. After TBI, dogs were maintained with parenteral fluids, antibiotics, and platelets (transfused for thrombocytopenic bleeding or prophylactically at a count of $20,000 / \mu \mathrm{l}$ or less). Before use all routine blood products were irradiated to $2,500 \mathrm{rad}$. Blood counts were obtained daily until death or full hematopoietic recovery occurred.

CFUc were plated in $0.3 \%$ agar using techniques described from this laboratory (12) with the following modifications: erythrocytes were removed from both blood and bone marrow using dextran sedimentation $(0.15 \mathrm{ml}$ of $3 \%$ Dextran $[223,000$ $\mathrm{mol} \mathrm{wt}] / \mathrm{ml}$ of sample) at $37^{\circ} \mathrm{C}$ for $15-20 \mathrm{~min}$ followed by lysis of residual erythrocytes by ammonium chloride-potassium lysing reagent obtained through the National Institutes of Health media room. Cultures were set up in supplemented McCoy's media containing $15 \%$ fetal calf serum (Gibco Laboratories, Grand Island Biological Company, Grand Island, N. Y.) (18) and $8 \%$ (vol/vol) plasma collected from a lethally irradiated dog $10 \mathrm{~d}$ after $900 \mathrm{rad}$ TBI and $4 \%$ (vol/vol) human placental conditioned media (19). These latter two reagents were added just before final plating. A measured inoculum of cell suspension containing $1 \times 10^{6}$ peripheral blood mono- 
nuclear cells and $<2.5 \times 10^{6}$ granulocytes $(20)$ were plated in a final volume of $1 \mathrm{ml}$ in $35-\mathrm{mm}$ Petri plates. Cultures were incubated for $7 \mathrm{~d}$ at $37^{\circ} \mathrm{C}$ in a fully humidified ambient atmosphere containing $7.5 \% \mathrm{CO}_{2}$, and colonies containing a minimum of 15 cells (20) counted in duplicate or quadruplicate plates. Bone marrow cells were plated in the same manner utilizing $1 \times 10^{6}$ nucleated bone marrow cells in $35-\mathrm{mm}$ Petri plates.

CFUc values reported are means \pm 1 (SEM). CFUc are reported in terms of $\mathrm{CFUc} / 10^{6}$ cells and as $\mathrm{CFUc} / \mathrm{ml}$. As previously noted (7) the latter value gives a better index of CFUc available for collection. This is particularly important following cyclophosphamide administration, when both CFUc per $10^{6}$ cells and cell counts per microliter are rapidly changing.

Statistical methods incorporated two-sided $P$ values in all cases. Intergroup variation was compared using the nonparametric Wilcoxon Rank Sum Test. Associations were analyzed using Spearman's Rank Correlation. Linear regression analysis was performed utilizing the master library statistics program of a T1-58 programmable calculator (Texas Instruments, Dallas, Texas).

\section{RESULTS}

Amplification of peripheral blood CFUc levels during post-cyclophosphamide leukocyte recovery.
As shown in Tables I and II, groups A and B were comparable with respect to base-line cell counts and CFUc levels in peripheral blood and bone marrow. Intravenous cyclophosphamide, $16 \mathrm{mg} / \mathrm{kg}$, was administered on two occasions $1 \mathrm{wk}$ apart (day 0 and 7) to each group A dog. This cyclophosphamide regimen was similar in timing and in resulting myelosuppression to the cyclophosphamide regimen that we had observed to be associated with CFUc expansion during leukocyte recovery in man (15). Mean leukocyte and platelet nadirs in group A dogs were, respectively, $870 \pm 170$ and $37,000 \pm 7,000 / \mu \mathrm{l}$. As shown in Fig. 1, leukocyte nadir typically occurred on day 10 after the administration of cyclophosphamide and was promptly followed by a period of rapid leukocyte recovery between days 13 and 17.

Serial measurements of blood and bone marrow CFUc levels were made on days 7 and 13-16 in four dogs and on days 13-17 in four dogs. Day 7 measurements were made prior to administering the second (day 7) dose of cyclophosphamide. These preliminary experiments were undertaken to document whether the association between chemotherapy-induced ex-

TABLE I

Peripheral Blood Cell Counts and Cellular Content of Cell Collections Obtained by Continuous Flow Centrifugation*

\begin{tabular}{|c|c|c|c|}
\hline & Group A & Group B $\$$ & $P$ \\
\hline \multicolumn{4}{|l|}{ Base-line blood counts } \\
\hline Hemoglobin, $g / 100 \mathrm{ml}$ & $17.2 \pm 0.3$ & $16.5 \pm 0.7$ & $\|$ \\
\hline Leukocytes, per $\mu l$ & $15,200 \pm 800$ & $14,200 \pm 600$ & $\|$ \\
\hline Platelets, per $\mu l$ & $306,000 \pm 28,000$ & $315,000 \pm 17,000$ & $\|$ \\
\hline \multicolumn{4}{|c|}{$\begin{array}{l}\text { Blood counts: immediately before } \\
\text { cell collection }\end{array}$} \\
\hline Hemoglobin, g/100 $\mathrm{ml}$ & $12.2 \pm 0.4$ & $15.6 \pm 0.4$ & $<0.01$ \\
\hline Leukocytes, per $\mu l$ & $8,600 \pm 1,500$ & $14,500 \pm 1,000$ & $<0.01$ \\
\hline Mononuclear cells, \% & $36 \pm 6$ & $30 \pm 2$ & $\|$ \\
\hline \multicolumn{4}{|l|}{ Cell collections } \\
\hline Volume, $m l$ & $373 \pm 37$ & $462 \pm 39$ & $\|$ \\
\hline Hemoglobin, g/100 $\mathrm{ml}$ & $3.2 \pm 0.4$ & $3.7 \pm 0.4$ & $\|$ \\
\hline Leukocytes, per $\mu l$ & $40,300 \pm 8,200$ & $35,700 \pm 4,600$ & $\|$ \\
\hline Mononuclear cells, \% & $59 \pm 6$ & $53 \pm 3$ & $\|$ \\
\hline Mononuclear cells, per $m l$ & $20.6 \pm 2.6 \times 10^{6}$ & $17.9 \pm 1.9 \times 10^{6}$ & $\|$ \\
\hline Platelets, per $\mu l$ & $440,000 \pm 70,000$ & $804,000 \pm 116,000$ & $<0.05$ \\
\hline \multicolumn{4}{|c|}{$\begin{array}{l}\text { Blood counts: immediately after } \\
\text { cell collections }\end{array}$} \\
\hline Hemoglobin, $\mathrm{g} / 100 \mathrm{ml}$ & $11.7 \pm 0.4$ & $14.4 \pm 0.7$ & $<0.01$ \\
\hline Leukocytes, per $\mu l$ & $5,700 \pm 1,100$ & $10,000 \pm 700$ & $<0.01$ \\
\hline Mononuclear cells, \% & $30 \pm 4$ & $21 \pm 4$ & $<0.05$ \\
\hline Platelets, per $\mu l$ & $48,000 \pm 7,000$ & $93,000 \pm 11,000$ & $<0.01$ \\
\hline
\end{tabular}

* Results expressed as mean \pm 1 SEM.

$\$ 14$ dogs, cyclophosphamide administered days 0 and 7. Cell collection between days 14-16. $\S 12$ dogs, cyclophosphamide not administered.

$\| P>0.10$. 
TABLE II

CFUc Measurements: Marrow, Blood, and Cell Collections Obtained by Continuous Flow Centrifugation*

\begin{tabular}{|c|c|c|c|}
\hline & Group At & Group $B \S$ & $P$ \\
\hline $\begin{array}{l}\text { Base-line bone marrow CFU } \\
\text { per } 10^{6} \text { nucleated cells } \\
\text { per ml of aspirate }\end{array}$ & $\begin{array}{c}249 \pm 60 \\
14,000 \pm 3,500\end{array}$ & $\begin{array}{c}136 \pm 32 \\
7,000 \pm 2,200\end{array}$ & " \\
\hline $\begin{array}{l}\text { Base-line peripheral blood C } \\
\text { per } 10^{6} \text { mononuclear cells } \\
\text { per ml of blood }\end{array}$ & $\begin{array}{c}12.9 \pm 3.8 \\
55 \pm 16\end{array}$ & $\begin{array}{l}9.8 \pm 3.0 \\
67 \pm 33\end{array}$ & " \\
\hline $\begin{array}{l}\text { Peripheral blood CFUc level } \\
\text { before cell collection } \\
\text { per } 10^{6} \text { mononuclear cells } \\
\text { per ml of blood }\end{array}$ & $\begin{array}{l}286 \pm 1119 \\
860 \pm 421^{* *}\end{array}$ & $\begin{array}{c}8.8 \pm 3.6 \\
34 \pm 15\end{array}$ & $\begin{array}{l}<0.01 \\
<0.01\end{array}$ \\
\hline $\begin{array}{l}\text { CFUc content of cell collecti } \\
\text { per } 10^{6} \text { mononuclear cells } \\
\text { per ml of collection }\end{array}$ & $\begin{array}{c}185 \pm 47 \\
3,300 \pm 800\end{array}$ & $\begin{array}{c}17 \pm 6 \ddagger \ddagger \\
300 \pm 100 \ddagger \ddagger\end{array}$ & $\begin{array}{l}<0.01 \\
<0.01\end{array}$ \\
\hline
\end{tabular}

* Results expressed as mean \pm 1 SEM.

$\ddagger$ As in Table I.

$\$$ As in Table I.

" $P<0.10$.

I Group A result 32-fold greater than group B result and 22-fold greater than group A pretreatment level.

** Group A result 25-fold greater than group B result and 16-fold greater than group A pretreatment level.

\$ Group A result 11-fold greater than group B result.

pansion of circulating CFUc levels and rapid postnadir leukocyte recovery previously observed in man would also occur in our study animals. Before cyclophosphamide we observed CFUc values of $55 \pm 16 / \mathrm{ml}$, and on days $7,13,14,15,16$, and 17 after the initiation of cyclophosphamide mean values of $2 \pm 1,210 \pm 115,825 \pm 420$, $1162 \pm 651,445 \pm 108$, and $285 \pm 132 \mathrm{CFUc} / \mathrm{ml}$, respectively, were observed. Thus, on days 14,15 , and 16 when leukocyte recovery was, in fact, occurring most rapidly, CFUc levels were expanded 15, 21, and 8-fold, respectively. In two dogs CFUc measurements on day 22 following the initial dose of cyclophosphamide revealed CFUc per milliliter values of 76 and 22 (mean $49 \pm 38$ ), suggesting return to base-line levels. These observations of CFUc expansion were, thus, consistent with our observations in man associating postnadir leukocyte recovery and peak periods of postchemotherapy expansion of circulating CFUc numbers. Based on these results days 14-16 were selected for cell collection in all dogs receiving cyclophosphamide. A total of 14 dogs were studied for CFUc expansion and peripheral blood leukocyte collection following cyclophosphamide and a median CFUc expansion of 18-fold (range 3-105) was observed. As shown in Table II the mean expansion of CFUc numbers per milliliter was 16-fold.
Canine peripheral blood mononuclear cell collections obtained by continuous flow centrifugation. Immediately before cell collection blood counts in group A dogs (hemoglobin, leukocyte, and platelets) were significantly lower than those observed in group B

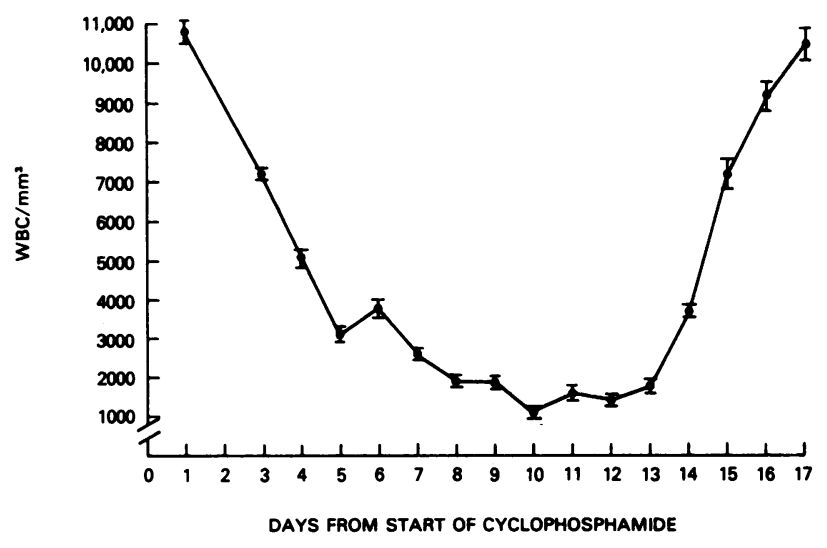

Figure 1 Mean leukocyte response to cyclophosphamide 16 $\mathrm{mg} / \mathrm{kg}$ given intravenously on days 0 and 7 . After leukocyte nadir on day 10 , postnadir recovery occurred rapidly between days 13 and 17. Circulating CFUc levels were most greatly expanded on days 14,15 , and 16 , and cell collections were made on these days. Error bars indicate 1 SE. WBC, leukocyte. 
dogs (Table I). This difference was a direct result of the myelosuppression that followed cyclophosphamide administration of group A dogs. Nevertheless, these differences did not hamper cell collection from the group A dogs and, as shown in Table I, comparable numbers of leukocytes and mononuclear leukocytes were collected from both groups. Collection was well tolerated, without mortality, in both groups. Immediately after cell collection, hemoglobin, leukocyte, and platelet counts were substantially lower in group A dogs (Table I), frequently to "clinically" significant levels, and platelet and erythrocyte transfusions were given prophylactically or because of thrombocytopenic bleeding from puncture wounds to a number of group A dogs.

These results show that peripheral blood stem cell collection was possible and reasonably well tolerated in all animals studied, even those with cyclophosphamide-induced suppression of peripheral blood counts. In addition, they also suggest that the myelosuppression observed in this setting did not impair collection of mononuclear leukocytes. This observation is important because hematopoietic stem cells are, morphologically, mononuclear leukocytes (21).

CFUc content of cell collections was strikingly increased in the group A dogs. As shown in Table II, collections from group A dogs contained 11-fold more CFUc per milliliter than collections from group B dogs. For purposes of comparison we measured the CFUc content of 20 normal canine marrows and observed that on a cell for cell basis, CFUc content of both group A peripheral blood leukocyte collections and normal canine marrow were strikingly similar (cell collection, $185 \pm 47$; marrow, $204 \pm 39 / 10^{6}$ cells; $P>0.10$ ).

Survival after TBI and infusion of peripheral blood cell collections. After 900 rad TBI, group A dogs received the following doses of cryopreserved autologous peripheral blood mononuclear cells: $1 \times 10^{8} / \mathrm{kg}$, four dogs; $0.5 \times 10^{8} / \mathrm{kg}$, four dogs; $0.25 \times 10^{8} / \mathrm{kg}$, one dog; $0.1 \times 10^{8} / \mathrm{kg}$, five dogs. Group B (no cytoxan) dogs received doses of $4 \times 10^{8} / \mathrm{kg}$, four dogs; $1 \times 10^{8} / \mathrm{kg}$, four dogs; $0.5 \times 10^{8} / \mathrm{kg}$, four dogs. $4 \times 10^{8}$ mononuclear cells/ $\mathrm{kg}$ was the maximum we could consistently collect in two, 4-h collections and the acute thrombocytopenia and anemia produced in dogs so managed discouraged us from attempting a third collection during the 7-d life span of our arteriovenous shunts. In contrast, $1 \times 10^{8}$ mononuclear cells $/ \mathrm{kg}$ could be easily collected in a single run lasting $2-3 \mathrm{~h}$.

In Fig. 2 we present the fraction of dogs at each cell dose who recovered leukocyte counts to a minimum of $1,000 / \mathrm{mm}^{3}$ and survived at least $40 \mathrm{~d}$ following TBI. Although the single group A dog that was given 0.25 $\times 10^{8}$ mononuclear cells $/ \mathrm{kg}$ did recover counts and survive, he is not included in this figure, because results in a single animal do not permit evaluation of

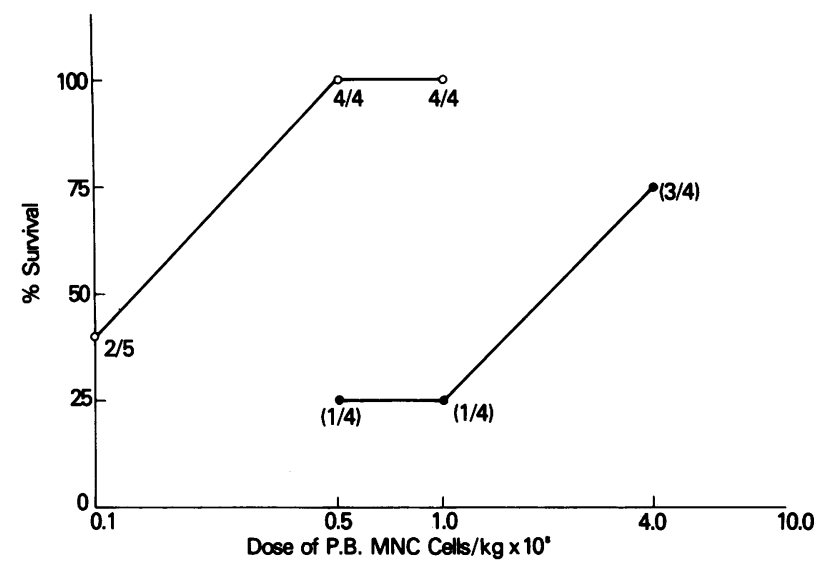

FigURE 2 Relationship between survival and dose of peripheral blood mononuclear cells (P. B. MNC) infused after 900 rad TBI. Group A dogs were given cells collected at times of cyclophosphamide-induced expansion of circulating CFUc levels (O). Group B dogs were given peripheral blood cells collected without CFUc expansion (O). Fractions at each dose point indicate dogs surviving (at least $40 \mathrm{~d}$ ) over dogs tested.

fractional survival. In this model, as previously described $(16,17)$, dogs achieving a leukocyte count of $1,000 / \mu \mathrm{l}$ achieve full hematopoietic recovery with granulocyte recovery paralleling leukocyte recovery and platelet recovery occurring with some delay, but usually within 3-5 wk of leukocyte recovery. Our experience was consistent in this regard; however, two of our animals did experience "late" hematopoietic deaths at day 36: one in group B (mononuclear cell dose, $4 \times 10^{8} / \mathrm{kg}$ ) that engrafted on day 22 but went on to die of thrombocytopenic hemorrhage, and one in group A (mononuclear cell dose, $0.1 \times 10^{8} / \mathrm{kg}$ ) that engrafted on day 22 but in which hematopoietic recovery was not sustained and septic death occurred on day 36 with a leukocyte count of $50 / \mu \mathrm{l}$. Consequently, we have chosen survival to day 40 as our criterion for sustained and reliable hematopoietic survival. There were no hematopoietic deaths (leukopenia, sepsis, or thrombocytopenic hemorrhage) seen after day 40 . One long-term survivor in group A died on day 76. At postmortem examination this dog was found to have a ruptured urinary bladder. Because the two dogs experiencing late hematopoietic death at day 36 did not demonstrate sustained hematopoietic recovery, they have not been included in Figs. 2 and 3 (vide infra). However, both animals had achieved leucocyte recovery to $1,000 / \mu \mathrm{l}$ prior to death and have been included in Fig. 4.

Although all of eight group A dogs given $0.5 \times 10^{8} /$ $\mathrm{kg}$ or more mononuclear cells survived, we were unable to demonstrate $100 \%$ survival for $40 \mathrm{~d}$ at any dose point for group B dogs including the $4 \times 10^{8} / \mathrm{kg}$ dose which represented the maximal number of mono- 


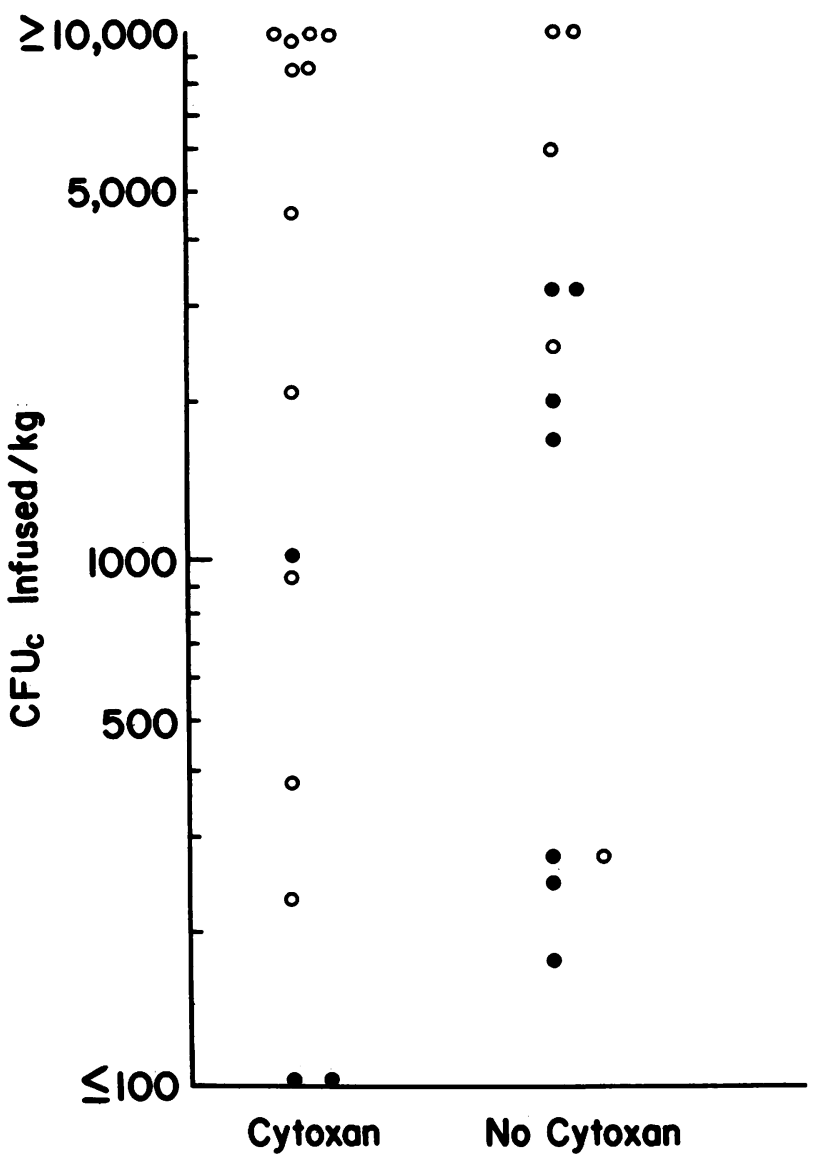

FIGURE 3 Relationship between CFUc dose and survival in group A (Cytoxan) and group B (no Cytoxan) animals. Open circles indicate dogs achieving hematopoietic recovery and surviving for at least $\mathbf{4 0} \mathrm{d}$. Closed circles indicate death without complete hematopoietic recovery.

nuclear cells consistently collectable in two full 4-h runs. At this dose the nonsurviving group $B$ dog did achieve a leukocyte count of $1,000 / \mu \mathrm{l}$, but, as noted, died on day 36 while still receiving platelet support. From Fig. 2 the estimated doses of peripheral blood mononuclear cells associated with $50 \%$ survival are $2.5 \times 10^{8} / \mathrm{kg}$ for group B and $0.2 \times 10^{8} / \mathrm{kg}$ for group A. The ratio of these two estimated $50 \%$ survival values is 12.5 and is numerically comparable to the 11-fold mean increase in CFUc content observed with group $\mathrm{A}$ collections.

Correlations among CFUc dose, survival, and rate of hematopoietic recovery. Fig. 3 relates survival, as defined for Fig. 2 (above), to CFUc dose per kilogram. In group A survival was consistently observed above $2 \times 10^{3} \mathrm{CFUc} / \mathrm{kg}$ and in group B survival was consistently observed above $6 \times 10^{3} \mathrm{CFUc} / \mathrm{kg}$. In the dose range of 0.3 to $5 \times 10^{3} \mathrm{CFUc} / \mathrm{kg}$ more group A dogs survived (four of five) than did group B dogs (one of

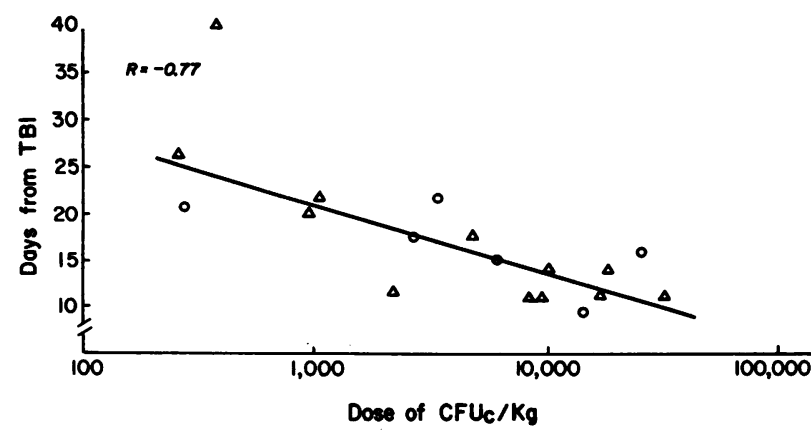

Figure 4 Relationship between CFUc dose and time to 1,000 leukocytes/ $\mu \mathrm{l}$ after $900 \mathrm{rad}$ TBI. Increasing CFUc doses provided more rapid hematopoietic recovery. Correlation significant at $P<0.01$ level. $O$, no cytoxan; $\Delta$, cytoxan pretreatment.

five), but this difference was not statistically significant $(P=0.20$, two-sided $t$ test).

Figure 4 relates rate of hematopoietic recovery (days to 1,000 leukocytes/ $\mathrm{mm}^{3}$ ) to CFUc dose. Linear regression analysis yielded an $R$ value of 0.77 and seemed to provide a reasonable fit of the observed data, suggesting correlation between rate of hematopoietic recovery and CFUc dose. Subsequently, analysis with Spearman's Rank Correlation confirmed significant association between CFUc dose and rate of hematopoietic recovery $(P<0.01)$.

As shown by the data in Fig. 2 and including the single group A dog who received $0.25 \times 10^{8}$ monocytes $/ \mathrm{kg}, 16$ animals were long-term survivors. In these animals median time to leukocyte counts of 500 and $1,000 / \mathrm{mm}^{3}$ and platelet counts of $50,000 / \mathrm{mm}^{3}$ were 13,14 , and $45 \mathrm{~d}$, respectively.

Thus, in this animal model, we observed that cyclophosphamide administration was associated with predictable and reliable expansion of circulating CFUc numbers and that this expansion permitted collection of large numbers of peripheral blood mononuclear cells that contained increased numbers of CFUc. Moreover, collections made during postcyclophosphamide expansion of circulating CFUc numbers were more potent in promoting hematopoietic reconstitution after an otherwise lethal dose of TBI than collections that did not contain increased numbers of CFUc. This suggests that in this setting, expansion of CFUc numbers was associated with a similar expansion of the more primitive hematopoietic stem cells (pluripotent) that are believed to be responsible for effecting hematopoietic reconstitution.

\section{DISCUSSION}

Using a canine model, we have shown that cyclophosphamide-induced expansion of peripheral blood CFUc numbers is associated with an increased capacity of 
peripheral blood mononuclear leukocytes to promote hematopoietic reconstitution after a hematopoietically lethal exposure to TBI. Based on our survival data in this study we estimated the $50 \%$ survival dose of cells collected during CFUc expansion to be $0.2 \times 10^{8}$ mononuclear cells $/ \mathrm{kg}$. The estimated $50 \%$ survival dose of cells collected without CFUc expansion was $2.5 \times 10^{8} /$ $\mathrm{kg}, 12.5$ times larger, a value which is numerically comparable to the 11-fold increased content of CFUc observed in cell collections made at times of CFUc expansion.

Our results show that in this setting CFUc values provide an excellent index of the ability of a population of peripheral blood mononuclear cells to promote hematopoietic reconstitution. In contrast, peripheral blood mononuclear cell dose, per se, does not. This result is similar to observations recently reported regarding CFUc content and the ability of human marrow collections to effect hematopoietic reconstitution (22). None of our results suggests that the reconstitutive potency of CFUc numbers was in any way acutely impaired by the use of cyclophosphamide (cf. Fig. 3). In this regard it is of interest that consistent survival was noted with fewer total CFUc $\left(\geq 2 \times 10^{3} / \mathrm{kg}\right)$ in the cyclophosphamide-treated dogs (group A) than in the control animals (group $\mathrm{B}, \geq 6 \times 10^{3} / \mathrm{kg}$ ). Although this difference was not statistically significant, it is possible that the ratio of CFUc to pluripotent stem cells available in the peripheral blood was altered during periods of CFUc expansion. Specifically, if this cyclophosphamide regimen resulted in a relatively greater expansion of pluripotent stem cell numbers than CFUc numbers on the days when cell collections were obtained, the number of CFUc required for consistent survival would be decreased. Whether the same expansion and behavior of both circulating CFUc and pluripotent stem cell numbers would have been observed under different experimental conditions is a matter for further study. However, in murine systems, as recently noted by Quesenberry and Levitt (23), manipulations that result in CFU proliferation or migration also result in CFUc proliferation or migration.

An interesting comparison may be made between our survival results with peripheral blood mononuclear cells containing increased CFUc numbers and previous observations with bone marrow cells made in the same canine model. Utilizing normal, autologous cryopreserved marrow cells, Gorin et al. (16), observed $43 \%$ survival among dogs given $0.1 \times 10^{8}$ nucleated bone marrow cells $/ \mathrm{kg}$. In the current study we observed $40 \%$ survival among group A dogs given $0.1 \times 10^{8}$ peripheral blood mononuclear cells/kg. Similarly, Gorin et al. (16) observed $100 \%$ survival among all dogs given a minimum of $0.5 \times 10^{8}$ nucleated bone marrow cells and in the current study we observed $100 \%$ survival among all group A dogs given at least $0.5 \times 10^{8}$ peripheral blood mononuclear cells $/ \mathrm{kg}$.

Unfortunately, CFUc data are not available from Gorin's study (16) to permit direct comparison of CFUc content between their bone marrow and our peripheral blood cell collections.

If our results in the group B animals were technically unfavorable, our group $A$ results might appear artificially superior. However, our group B data compare favorably with prior studies using peripheral blood mononuclear cells collected from dogs in the absence of CFUc expansion. For example, Sarpel et al. (6) observed survival in four of four dogs given $1 \times 10^{9}$ peripheral blood mononuclear cells/kg and Nothdurft et al. (7) observed long-term survival in three of four dogs given $3-6 \times 10^{8}$ mononuclear cells $/ \mathrm{kg}$. Our results in our group B dogs are completely consistent with those previously published experiences (three of four survivors at a dose of $4.0 \times 10^{8}$ mononuclear cells $/ \mathrm{kg}$ ). Our CFUc values are also consistent with those provided in these same two studies, both in terms of levels in the peripheral blood prior to treatment and in terms of doses associated with survival.

These results also suggest that with proper attention to post collection blood counts, especially hemoglobin and platelet levels, large numbers of peripheral blood mononuclear cells and circulating hematopoietic stem cells can be safely collected after cyclophosphamide administration in spite of associated, transient myelosuppression. After cell collection, acute hematopoietic recovery continues in an uninterrupted manner.

In conclusion, these results suggest that observed expansion of circulating CFUc numbers in man following nonintensive, systemic chemotherapy $(14,15)$ may permit collection of circulating hematopoietic stem cells in numbers adequate to effectively promote hematopoietic reconstitution. Such a result would be consistent with current studies in patients with chronic myelogenous leukemia (13), and would be a major step forward in developing further clinical applications for autologous hematopoietic reconstitution.

\section{REFERENCES}

1. Goodman, J. W., and G. S. Hodgson. 1962. Evidence for stem cells in the peripheral blood of mice. Blood. 10: $702-714$.

2. Debelak-Fehir, K. M., R. Catchatourian, and R. B. Epstein. 1975. Hematopoietic colony forming units in fresh and cryopreserved peripheral blood cells of canines and man. Exp. Hematol. (Oak Ridge). 3: 109-115.

3. Storb, R. T., T. C. Graham, R. B. Epstein, G. E. Sale, and E. D. Thomas. 1977. Demonstration of Hematopoietic stem cells in the peripheral blood of baboons by cross circulation. Blood. 50: 537-542.

4. McKredie, K. B., E. M. Hersh, and E. J. Freireich. 1971. Cells capable of colony formation in the peripheral blood of man. Science (Wash. D. C.) 171: 293-294. 
5. Barr, R. D., J. Whang-Peng, and S. Perry. 1975. Hematopoietic stem cells in human peripheral blood. Science (Wash. D. C.) 190: 284-285.

6. Sarpel, S. C., A. R. Zander, L. Horvath, and R. B. Epstein. 1979. The collection, preservation and function of peripheral blood hematopoietic cells in dogs. Exp. Hematol. (Oak Ridge). 7: 113-120.

7. Nothdurft, W., C. Bruch, T. M. Fliedner, and E. Ruber. 1977. Studies on the regeneration of the CFUc population in blood and bone marrow of lethally irradiated dogs after autologous transfusions of cryopreserved mononuclear cells. Scand. J. Haematol. 19: 470-481.

8. Deisseroth, A., and R. A. Abrams. 1979. The role of autologous stem cell reconstitution in intensive therapy for resistant neoplasms. Cancer Treat. Rep. 63: 461-471.

9. Rich, K. C., C. M. Richman, S. E. Mejia, and P. Daddona. 1980. Immunoreconstitution by peripheral blood leukocytes in adenosine deaminase-deficient severe combined immunodeficiency. J. Clin. Invest. 66: 389-395.

10. Abrams, R. A., D. Glaubiger, R. Simon, A. Lichter, and A. B. Deisseroth. 1980. Haemopoietic recovery in Ewing's sarcoma after intensive combination therapy and autologous marrow infusion. Lancet. II 385-389.

11. Hershko, D., R. P. Gale, W. G. Ho, and M. V. Cline. 1979. Cure of aplastic anemia in proxysmal nocturnal hemoglobinuria by marrow transfusion from identical twin: failure of peripheral leukocyte transfusion to correct marrow aplasia. Lancet. I: 945-947.

12. Abrams, R. A., D. Glaubiger, F. R. Appelbaum, and A. B. Deisseroth. 1980. Result of attempted hematopoietic reconstruction using isologous peripheral blood mononuclear cells: a case report. Blood. 56: 516-520.

13. Goldman, J. M. 1978. Modern approaches to the management of chronic granulocytic leukemia. Semin. Hematol. 15: $420-430$.

14. Richman, C. M., R. S. Weiner, and R. A. Yankee. 1976. Increase in circulating stem cells following chemotherapy in man. Blood. 47: 1031-1039.
15. Abrams, R. A., A. Johnston-Early, C. Kramer, J. D. Minna, M. H. Cohen, and A. B. Deisseroth. 1981. Amplification of circulating granulocyte-monocyte stem cell (CFUc) numbers following chemotherapy in patients with extensive small cell carcinoma of the lung. Cancer Res. 41: 35-41.

16. Gorin, N. C., G. Herzig, M. I. Bull, and R. G. Graw, Jr. 1978. Long-term preservation of bone marrow and stem cell pool in dogs. Blood. 51: 257-265.

17. Appelbaum, F. R., G. Herzig, R. G. Graw, M. I. Bull, C. Bowler, N. C. Gorin, and A. B. Deisseroth. 1978. Study of cell dose and storage time on engraftment of cryopreserved autologous bone marrow in a canine model. Transplantation (Baltimore). 26: 245-248.

18. Pike, B. L., and W. A. Robinson. 1970. Human bone marrow colony growth in agar gel. J. Cell. Physiol. 76: 77-84.

19. Burgess, A. W., E. M. A. Wilson, and D. Metcalf. 1977. Stimulation by human placental conditioned medium of hemopoietic colony formation by human marrow cells. Blood. 49: 573-583.

20. Kovacs, P., C. Bruch, and T. M. Fliedner. 1976. Colony formation by canine hematopoietic cells in vitro. Inhibition by polymorphonuclear leukocytes. Acta Haematol. (Basel). 56: 107-115.

21. Ross, W. M., M. Korbling, W. Nothdurft, W. Calvo, and T. M. Fliedner. 1977. Characterization of bone marrow and lymph node repopulating cells by transplanting mononuclear cells into radiated dogs. In Experimental Hematology Today. S. J. Baum and G. D. Ledney, editors. Springer-Verlag, New York. 29-37.

22. Spitzer, G., D. S. Verma, R. Fisher, A. Zander, L. Vellekoop, J. Litam, K. B. McCredie, and K. A. Dicke. 1980. The myeloid progenitor cell: its value in predicting hematopoietic recovery after autologous bone marrow transplantation. Blood. 55: 317-323.

23. Quesenberry, P., and L. Levitt. 1979. Hematopoietic stem cells. II. N. Engl. J. Med. 301: 819-823. 